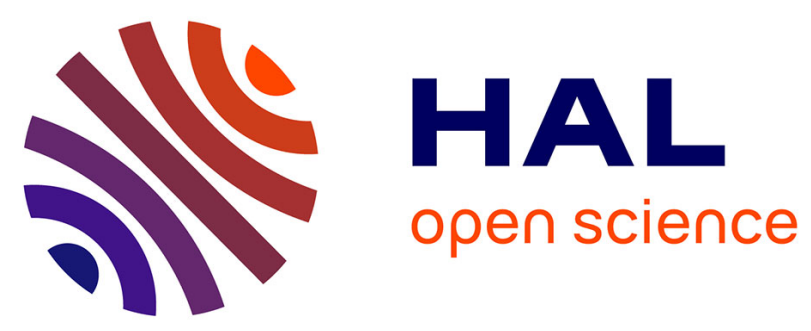

\title{
Effect of Nafion and platinum content in a catalyst layer processed in a radiofrequency helicon plasma system
}

Amaël Caillard, Ch. Charles, Devin Ramdutt, Rod W. Boswell, Pascal Brault

\section{To cite this version:}

Amaël Caillard, Ch. Charles, Devin Ramdutt, Rod W. Boswell, Pascal Brault. Effect of Nafion and platinum content in a catalyst layer processed in a radiofrequency helicon plasma system. Journal of Physics D: Applied Physics, 2009, 42, pp.045207. 10.1088/0022-3727/42/4/045207 . hal-00355750

\section{HAL Id: hal-00355750 \\ https://hal.science/hal-00355750}

Submitted on 23 Jan 2009

HAL is a multi-disciplinary open access archive for the deposit and dissemination of scientific research documents, whether they are published or not. The documents may come from teaching and research institutions in France or abroad, or from public or private research centers.
L'archive ouverte pluridisciplinaire $\mathbf{H A L}$, est destinée au dépôt et à la diffusion de documents scientifiques de niveau recherche, publiés ou non, émanant des établissements d'enseignement et de recherche français ou étrangers, des laboratoires publics ou privés. 


\title{
Effect of Nafion and platinum content \\ in a catalyst layer processed in a \\ radio frequency helicon plasma system
}

\author{
A. Caillard ${ }^{1}$, C. Charles ${ }^{1,3}$, D. Ramdutt ${ }^{1}$, R. Boswell ${ }^{1}$, P. Brault ${ }^{2}$ \\ ${ }^{1}$ Space Plasma, Power and Propulsion group, Research School of Physical Sciences and Engineering, \\ The Australian National University, Canberra, ACT 0200, Australia \\ ${ }^{2}$ Groupe de Recherche sur l'Energétique des Milieux Ionisés, UMR6606 Université d'Orléans - CNRS \\ Polytech'Orléans, BP6744, F-45067 Orléans Cedex 2, France
}

\section{E-mail addresses}

amael.caillard@univ-orleans.fr, christine.charles@anu.edu.au, devin.ramdutt@,rsphysse.anu.edu.au, rod.boswell@anu.edu.au and Pascal.Brault@univ-orleans.fr

\begin{abstract}
A helicon plasma sputtering system is used to deposit small amounts of platinum on microporous carbon support composed of Vulcan XC 72 carbon particles (known as gas diffusion layer - GDL) to form Pt catalysed electrodes for proton exchange membrane fuel cells (PEMFC). Electrodes with low Pt loading are prepared, assembled in custom-made membrane electrode assemblies (MEAs) and tested for the hydrogen oxydation and the oxygen reduction. Initially, the Nafion ${ }^{\circledR}$ loading spread on these plasma prepared electrodes is optimized by measuring the MEA performance. It is found that the optimum Nafion ${ }^{\circledR}$ loading is $1 \mathrm{mg} \mathrm{cm}^{-2}$ for an electrode previously covered with $0.1 \mathrm{mg}_{\mathrm{Pt}} \mathrm{cm}^{-2}$ using the helicon plasma system. For a commercial electrode prepared by ink-processes with $0.5 \mathrm{mg}_{\mathrm{Pt}} \mathrm{cm}^{-2}$, the optimized Nafion ${ }^{\circledR}$ loading is $2 \mathrm{mg}$ $\mathrm{cm}^{-2}$. Using the respective optimized Nafion ${ }^{\circledR}$ loading, the electrical performance of the custom-made MEA with one plasma prepared electrode (either anode or cathode) is compared with that of a reference MEA from Electrochem Inc. (Pt loading per electrode of $0.5 \mathrm{mg} \mathrm{cm}^{-2}$ and maximum power density of $425 \mathrm{~mW} \mathrm{~cm}^{-2}$ ) without gas humidification. The custom-made MEA fitted with an anode covered with $0.005 \mathrm{mg}_{\mathrm{Pt}} \mathrm{cm}^{-2}$ leads to the same performance than that of the reference MEA at low current density $\left(<500 \mathrm{~mA} \mathrm{~cm}^{-2}\right)$ and high gas backpressure ( 3 bar). This result indicates that the catalyst utilization efficiency in the plasma prepared anode is 100 times higher than that in the commercial anode $\left(85 \mathrm{~kW} \mathrm{~g}_{\mathrm{Pt}_{\mathrm{t}}}^{-1} v s 0.85 \mathrm{~kW} \mathrm{~g}_{\mathrm{Pt}_{\mathrm{t}}}{ }^{-1}\right)$. For plasma prepared cathodes with $0.1 \mathrm{mg}_{\mathrm{Pt}} \mathrm{cm}^{-2}$, the cathodic Pt utilization efficiency is $2.7 \mathrm{~kW} \mathrm{~g}_{\mathrm{Pt}}{ }^{-1}$, which is 3 times higher than that obtained in the commercial cathode.
\end{abstract}

Keywords: Fuel cells; Plasma; sputtering; Nafion ${ }^{\circledR}$; platinum; utilization

PACS classification codes : 81.15.Cd, 82.47.Gh

Submitted to Plasma Sources Science and Technology

${ }^{3}$ Author to whom any correspondence should be addressed. 


\section{Introduction}

Over the past few years, scientists, politicians and economists have become increasingly aware of the impending oil peak and the present global warming. A progressive transition from the hydrocarbon economy to a hydrogen economy is one of the solutions to reduce greenhouse gas emissions and to face the dwindling supplies of petroleum. In such an economy, the energy required for motive power (automobiles or other vehicles) or electricity (stationary applications) will be derived from a reaction involving hydrogen $\left(\mathrm{H}_{2}\right)$ and oxygen. However, many improvements are needed to achieve this transition in terms of $\mathrm{H}_{2}$ production, $\mathrm{H}_{2}$ storage and fuel cell (FC) cost and efficiency.

Proton Exchange Membrane Fuel Cells (PEMFC) using solid polymer membranes and operating at low temperatures $\left(\leq 100{ }^{\circ} \mathrm{C}\right)$ must deliver high power densities with an ultra-low content of platinum catalyst to reduce cost for mass commercialization. According to the US Department of the Energy (DoE), the cost of the electrocatalyst must be decreased to $5 \mathrm{SW}^{-1}$ [1] and the maximum power density delivered by the MEA must reach $1 \mathrm{~W} \mathrm{~cm}^{-2}$ (and $0.25 \mathrm{~W} \mathrm{~cm}^{-2}$ at $0.8 \mathrm{~V}$ ). However, the platinum loading in a PEMFC electrode is currently in the range $0.3-0.5 \mathrm{mg}_{\mathrm{Pt}} \mathrm{cm}^{-2}$ leading to electrical performance of $0.7-0.9 \mathrm{~W} \mathrm{~cm}^{-2}$ with a thin solid polymer membrane (usually Nafion ${ }^{\circledR} 112$ ). This represents a Pt cost of $48 \$ \mathrm{~kW}^{-1}$ (considering a Pt cost of 48 $\$ \mathrm{~g}_{\mathrm{Pt}}$ on dec. 2007). Consequently, the Pt loading must be reduced by a factor of 10 (a least) in the MEA to achieve the DoE target. Therefore, both an increase of the electrical performances of PEMFCs and a decrease of the platinum loading in the MEA are of interest.

A PEMFC electrode is usually prepared by ink processes and consists of a microporous gas diffusion layer (GDL, mixture of carbon particles and PTFE particles) brushed on a macroporous carbon support such as carbon cloth or carbon paper, and of a microporous catalyst layer (mixture of proton conductive polymer and platinum catalyst nano-clusters supported on carbon particles).

Many deposition methods (such as spraying [2-4], screen-printing [5], electro-deposition [6,7] and sputtering [8-26]) have recently been developed to disperse the Pt content close to the electrode-membrane interface [27]where electrochemical reactions take place. Among these catalyst layer fabrication methods, plasma sputtering techniques show great potential for increasing the Pt efficiency by reducing the catalyst layer thickness and controlling the platinum content and morphology (carbon-supported Pt nano-clusters size $<10 \mathrm{~nm})$.

To provide ample contact between the Nafion ${ }^{\circledR}$ membrane and the Pt catalyst, a Nafion ${ }^{\circledR}$ solution is usually added to the catalysed electrode. The Nafion ${ }^{\circledR}$ content in the electrode is generally expressed as mg $\mathrm{cm}^{-2}$ or as wt.\% (dry weight of Nafion ${ }^{\circledR}$ ionomer divided by the weight of $\mathrm{Pt} / \mathrm{C}$ catalyst + dry weight of Nafion ${ }^{\circledR}$ ionomer, multiplied by 100). The appropriate loading of Nafion ${ }^{\circledR}$ required for the best performing MEAs has been previously investigated for the electrode prepared by ink processes [28-35]. The optimum Nafion ${ }^{\circledR}$ content is about 30-40\% and increases with decreasing Pt loading [33]. However, the effect of Nafion ${ }^{\circledR}$ loading in electrodes catalysed by plasma sputtering remains unclear.

One of the challenges in the fabrication of electrodes by plasma sputtering is the optimization of the MEA electrical performance by adjusting the fabrication process involving notably the Pt sputtering deposition and the subsequent Nafion ${ }^{\circledR}$ coating. The objective of this work is to study the effect of the 
catalyst and of the Nafion ${ }^{\circledR}$ loading by assessing the performance of MEAs fitted with low Pt loaded electrodes prepared by plasma sputtering.

\section{Experimental}

\subsection{Electrode prepared in the plasma sputtering reactor, Southern Cross}

Different pieces of $5 \mathrm{~cm}^{2}$ GDL microporous layer supported on woven web (LT1400W, purchased from BASF Fuel cell Inc.) are covered by platinum in the plasma sputtering set-up called Southern Cross. This reactor has been previously detailed $[36,37]$ and is shown on Figure 1. In summary, a low pressure argon plasma is created by a double saddle antenna surrounding a glass tube and powered by a $13.56 \mathrm{MHz}$ radio frequency generator. The base pressure before a Pt deposition is less than $10^{-6}$ bar and is achieved by a primary and a turbomolecular pump. The horizontal GDL holder is placed at $18 \mathrm{~cm}$ below the glass tube, whereas the vertical Pt target biased at $-300 \mathrm{~V}$ is installed $6 \mathrm{~cm}$ above the GDL holder. For the present experiments, the argon flow is fixed at $60 \mathrm{sccm}$ which leads to argon pressure $\mathrm{P}$ of $5 \mu$ bar. The RF power is fixed at around $600 \mathrm{~W}$ leading to a argon ion current on the $5 \times 5 \mathrm{~cm}^{2} \mathrm{Pt}$ target of $40 \mathrm{~mA}$. After plasma ignition, Pt atoms are ejected from the target which is submitted to the bombardment of the argon ions, travel through the plasma and deposit on the GDL. For these conditions, the deposition rate of platinum on the rotating GDL reaches $5 \mu \mathrm{g}_{\mathrm{Pt}} \mathrm{cm}^{-2} \mathrm{~min}^{-1}$ from previous measurements by Rutherford backscattering spectroscopy (RBS) [38].

In this study, different amounts of platinum (from 5 to $100 \mu \mathrm{g}_{\mathrm{Pt}} \mathrm{cm}^{-2}$ ) are deposited on different pieces of GDL in successive deposition experiments. In this case, the Pt wt.\%/C catalyst ratio varies from 0.08 to 2 by assuming that each GDL is coated by a carbon loading of $5 \mathrm{mg} \mathrm{cm}^{-2}$. However, it has been previously shown that plasma sputtering induces a Pt atom penetration depth of $2 \mu \mathrm{m}$ in the GDL [11], which represents about $2 \%$ of the entire GDL thickness. Consequently, the estimated local Pt wt.\%/C catalyst ratio is between 5 and 100 in this $2 \mu \mathrm{m}$ thick catalytic layer.

A cold field scanning electron microscopy (SEM, Hitachi S4500) is used to characterize the sputtered Pt catalyst on the Vulcan based GDL.

After the Pt deposition, a Nafion ${ }^{\circledR} 5$ wt.\% (PowerIon Inc.) solution is spread onto the plasma catalysed electrodes using a pipette to ensure proton access from the membrane to Pt catalyst sites. It is assumed that the entire quantity of added Nafion ${ }^{\circledR}$ remains in the electrode. After the application of the Nafion ${ }^{\circledR}$ solution the electrodes are dried in an oven at $50{ }^{\circ} \mathrm{C}$ for 1 hour. 


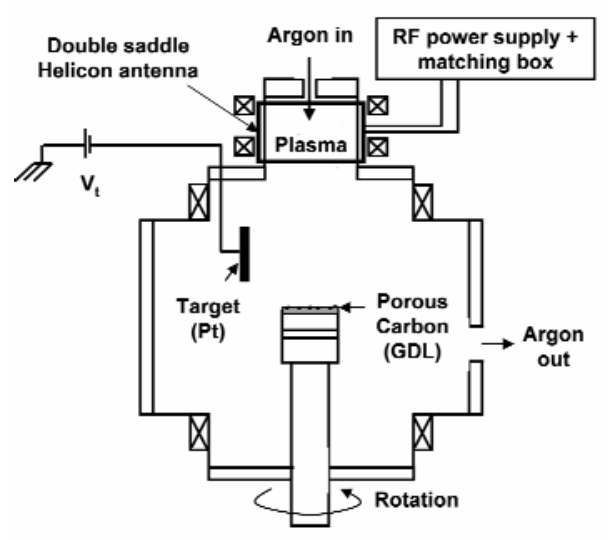

Figure 1. Schematic of Southern Cross, the plasma sputtering reactor.

\subsection{Commercial electrode prepared by ink processes}

The commercial electrode (LT 120E-W) purchased from BASF Fuel cell Inc. contains $0.5 \mathrm{mg}_{\mathrm{Pt}} \mathrm{cm}^{-2}$ of platinum which corresponds to a Pt wt./C ratio of around $10 \%$. The Nafion ${ }^{\circledR} 5 \mathrm{wt} . \%$ solution is added to each piece of $5 \mathrm{~cm}^{2}$ electrodes.

\subsection{Membrane preparation and custom-made MEA}

The Nafion ${ }^{\circledR} 115$ proton conducting membrane (Electrochem. Inc.) is treated in hydrogen peroxide at $60{ }^{\circ} \mathrm{C}$ for 1 hour, rinsed in de-ionised water, treated in $1 \mathrm{M}$ sulphuric acid at $600{ }^{\circ} \mathrm{C}$ for 1 hour and finally rinsed in de-ionised water at $600{ }^{\circ} \mathrm{C}$ for 1 hour. The cleaned membrane is then stored in de-ionised water at room temperature.

Two $5 \mathrm{~cm}^{2}$ electrodes and a humidified Nafion ${ }^{\circledR} 115$ membrane placed in between are pressed at $130{ }^{\circ} \mathrm{C}$ for $120 \mathrm{~s}$ under a pressure of $2 \mathrm{kN} \mathrm{cm}^{-2}$. Two types of electrode are used: either a commercial electrode or a GDL containing different amounts of sputtered platinum. In this study, most of the MEAs are asymmetric (commercial electrode at the anode and plasma prepared electrode at the cathode or vice versa).

\subsection{Reference MEA}

All the custom-made MEAs are compared to a reference MEA (FC05-MEA, Electrochem. Inc.) composed of a Nafion ${ }^{\circledR} 115$ membrane, two reference electrodes with a platinum loading of $0.5 \mathrm{mg}_{\mathrm{Pt}} \mathrm{cm}^{-2}$ supported on carbon paper. The geometric active surface area of this MEA is $5 \mathrm{~cm}^{2}$.

\subsection{Fuel cell tests}

To obtain an operating cell with a surface area of $5 \mathrm{~cm}^{2}, 10$ mils thick silicon gaskets (EC-GS-SIL-10-05SP, Electrochem. Inc.), carbon bipolar plates (FC05-MPR, Fuel cell store), gold plated current collectors copper plates (FC-05-CP, Electrochem. Inc.) are added on each side on the (custom-made or commercial) MEA. A torque of $2 \mathrm{Nm}$ is applied on each of the eight bolts clamping the fuel cell. The tests are carried on a MTS 150 Fuel Cell Station manufactured by Quintech. Details about the station are given elsewhere [39]. In summary, the station includes a custom-made system controlling the mass flow rates, the temperature of the 
input gas lines and the humidifiers. In this study, dry hydrogen and dry oxygen are used as fuel and oxidant, respectively. All cell voltage vs. current density curves (known as polarization curves) are obtained at a cell temperature of $80{ }^{\circ} \mathrm{C}$. The anode backpressures $\left(\mathrm{P}_{\mathrm{a}}\right)$ and the cathode backpressure $\left(\mathrm{P}_{\mathrm{c}}\right)$ are set at the same value.

In the section detailing the effect of the Pt loading on the cathode performance, the polarization curves are treated by the following equations (rewriting of the Tafel equation) to draw some kinetic data:

$\mathrm{E}=\mathrm{E}_{0}-\mathrm{b} \log j-\mathrm{R}_{\text {cell }} j$

$\mathrm{E}_{0}=\mathrm{Er}+\mathrm{b} \log j_{0}$

where $j$ is the current density at the potential $\mathrm{E}, \mathrm{E}_{\mathrm{r}}$ the reversible potential of the cell, $j_{0}$ and $\mathrm{b}$ the exchange current density and Tafel slope for the oxygen reduction reaction (ORR), respectively, and $\mathrm{R}_{\text {cell }}$ is the overall resistance causing the linear variation in the cell potential versus current density $(j)$. We analyse the electric data up to the end of the linear region of the $\mathrm{E}(j)$ curves. The square of the correlation coefficient is always taken higher than 0.98 . This treatment assumes that mass transport limitations and activation overpotentials at the anode are negligible, and assumes that the reactants act as ideal gases (their activity equals their partial pressure) and that the activity of water is 1.

The efficiency of the catalyst utilization in the cathode is determined by dividing the output power of the

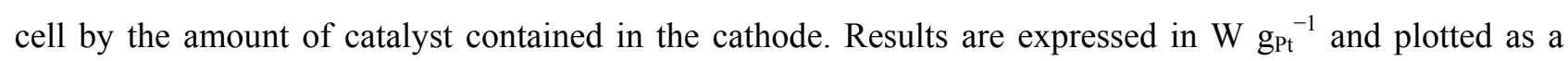
function of the current density.

\section{Results and discussion}

\subsection{Morphology of the Pt deposition}

SEM micrographs of the surface of the porous GDL after a platinum deposition time of 1, 4 and 20 min are displayed on Figure 2a, Figure $2 \mathrm{~b}$ and Fig 2c, respectively. This corresponds to a total Pt loading of 0.005, 0.020 and $0.100 \mathrm{mg}_{\mathrm{Pt}} \mathrm{cm}^{-2}$. Figure $2 \mathrm{a}$ shows that all visible Vulcan particles of the GDL are coated by nanoclusters made of platinum determined from ex situ RBS measurements. The size of the Pt nano-clusters is in the range 3-7 $\mathrm{nm}$ with an average diameter of $5 \mathrm{~nm}$. Also the Pt nano-clusters can still be seen on the GDL surface (Figure 2b), the coverage of the carbon Vulcan particle is close to $100 \%$. Figure 2c shows the formation of a platinum thin film surrounding the Vulcan particles leading to an apparent increase of their diameter by a few tens of nm. 


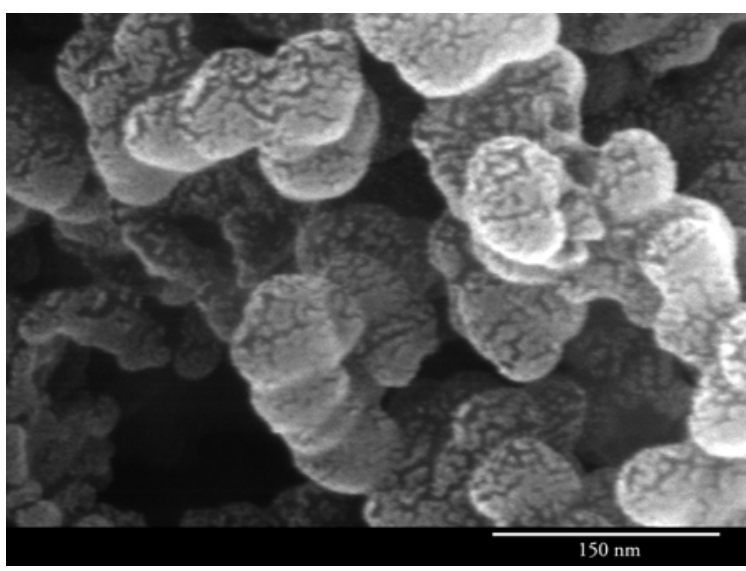

(a)

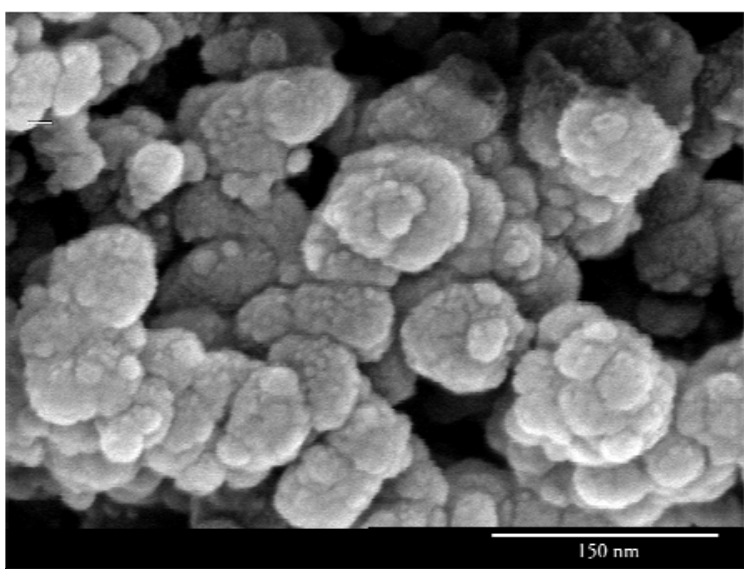

(b)

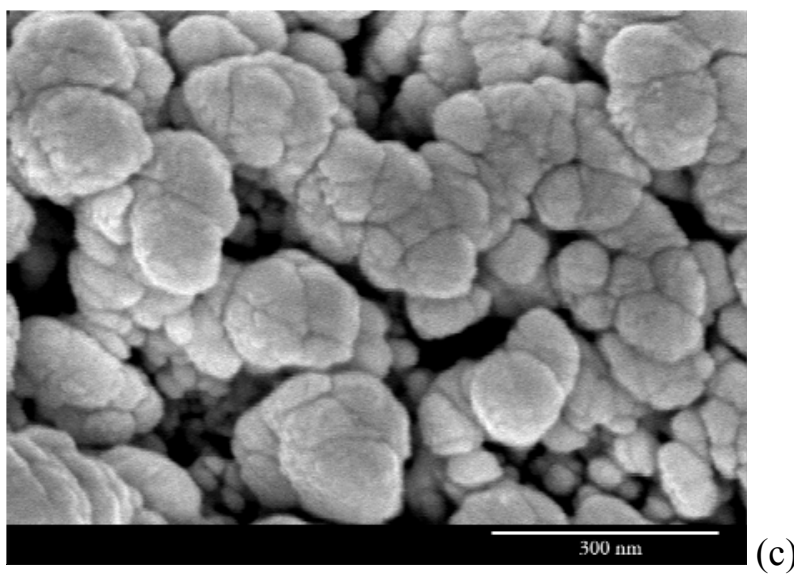

Figure 2. SEM images of Pt nano-clusters and thin film deposited by plasma sputtering on the carbon particles of a GDL: (a) $0.0050 .02 \mathrm{mg}_{\mathrm{Pt}} \mathrm{cm}^{-2}$ (b) $0.02 \mathrm{mg}_{\mathrm{Pt}} \mathrm{cm}^{-2}$ and (c) $0.1 \mathrm{mg}_{\mathrm{Pt}} \mathrm{cm}^{-2}$. RF Power generator: 500W; target bias: $-300 \mathrm{~V}$; pressure: $0.5 \mathrm{~Pa}$; Pt target current: $50 \mathrm{~mA}$.

\subsection{Fuel cell performance versus Nafion ${ }^{\circledR}$ loading}

i) Custom-made MEA with two commercial electrodes

Different quantities of Nafion ${ }^{\circledR}$ solution (corresponding to a dry weight of $0.25,1,2,2.5$ and $3 \mathrm{mg} \mathrm{cm}^{-2}$ ) are spread on five pairs of commercial electrodes assembled into custom-made MEAs using Nafion ${ }^{\circledR} 115$ membrane. Figure 3 displays the polarization curve (voltage $E$ vs. current density $j$ ) obtained with these five MEAs and with the reference MEA (black solid line). The performance for a Nafion ${ }^{\circledR}$ loading of $0.25 \mathrm{mg} \mathrm{cm}$ ${ }^{2}$ (diamonds on Figure 3) is much poorer than that of the reference MEA (black line). The performance 
increases with increasing Nafion ${ }^{\circledR}$ loading to reach that of the reference MEA for a loading of $2 \mathrm{mg} \mathrm{cm}{ }^{-2}$ (crosses). A further increase of the Nafion ${ }^{\circledR}$ loading $\left(>2 \mathrm{mg} \mathrm{cm}^{-2}\right)$ yields a reduction the performance. The power density achieved by the reference MEA is shown by a dashed line on Figure 3 and corresponds to a maximum value of $425 \mathrm{~mW} \mathrm{~cm}^{-2}$.

For a Nafion ${ }^{\circledR}$ loading lower than $2 \mathrm{mg} \mathrm{cm}^{-2}$ (diamonds and triangles), the cell voltage achieved by the custom-made MEA is slightly lower than that of the reference MEA at low current density. The decrease of performance is much more visible at high current density. This behaviour suggests that the poor performance of the custom-made MEA is related to a high overall resistance of the MEA which has a more pronounced effect at high current density and to reduced reaction kinetics. This results from the combination of three mechanisms: a high contact resistance between the electrolyte and the catalyst, a discontinuous dispersion of the Nafion ${ }^{\circledR}$ polymer in the electrode and a smaller number of three-phase interfaces $\mathrm{Pt} / \mathrm{C} / \mathrm{Nafion}{ }^{\circledR}$ within the electrode, and hence a lower Pt utilization.

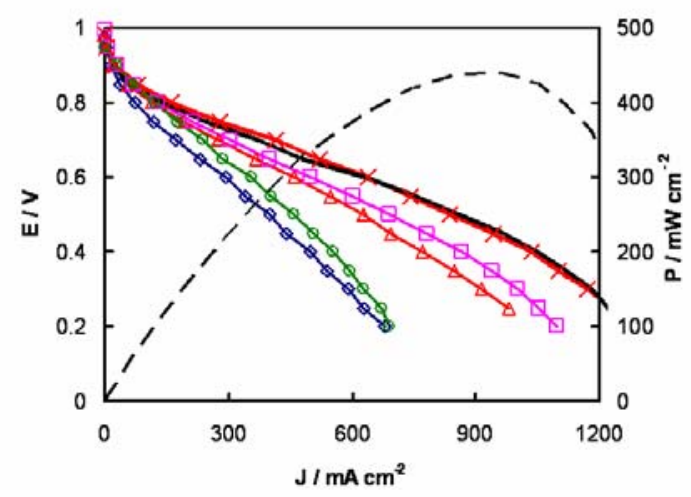

Figure 3. Cell voltage $E$ vs. current density $j$ obtained for five custom-made MEAs composed of two commercial electrodes both covered by different Nafion ${ }^{\circledR}$ loadings : $(\bullet-) 0.25 \mathrm{mg} \mathrm{cm}^{-2},\left({ }_{-}\right) 1 \mathrm{mg} \mathrm{cm}^{-2},\left({ }_{-}\right)$ $2 \mathrm{mg} \mathrm{cm}^{-2}(\square) 2.5 \mathrm{mg} \mathrm{cm}^{-2}$ and $(-) 3 \mathrm{mg} \mathrm{cm}^{-2}$. A Nafion ${ }^{\circledR} 115$ membrane completes the five custom-made MEAs. The MEA $A_{\text {ref }}$ is composed of two reference electrodes with a Pt loading of $0.5 \mathrm{mg}_{\mathrm{Pt}} \mathrm{cm}^{-2}$ and a Nafion ${ }^{\circledR}$ 115 membrane. Fuel cell operating conditions: $T_{\text {cell }}=80{ }^{\circ} \mathrm{C}, \mathrm{P}_{\mathrm{a}}=\mathrm{P}_{\mathrm{c}}=3$ bar, $\mathrm{D}_{\mathrm{a}}=\mathrm{D}_{\mathrm{c}}=0.06 \mathrm{~L} \cdot \mathrm{min}^{-1}$.

When the Nafion ${ }^{\circledR}$ content increases further than $2 \mathrm{mg} \mathrm{cm}^{-2}$ (squares and circles), the high cell voltage at low current density is conserved up to around $200 \mathrm{~mA} \mathrm{~cm}^{-2}$, and drops afterwards. This decrease of performance at medium and especially high current density is related to a high overall resistance of the MEA (in particular the mass transport resistance) due to the large amount of Nafion ${ }^{\circledR}$ blocking the pores in the electrode and reducing the gas permeability. Some catalyst sites covered by a thick layer of Nafion ${ }^{\circledR}$ may be inactive as well. In other words, this mass transport limitation results from an increase of the distance through which the gas has to permeate, diffuse, or migrate.

For this reason, a Nafion ${ }^{\circledR}$ loading of $2 \mathrm{mg} \mathrm{cm}^{-2}$ is added on each commercial electrode used in all the following FC tests. As this electrode has a $\mathrm{Pt} / \mathrm{C}$ ratio of $10 \mathrm{wt} \%$ and a $\mathrm{Pt}$ loading of $0.5 \mathrm{mg}_{\mathrm{Pt}} \mathrm{cm}^{-2}$, this optimum Nafion ${ }^{\circledR}$ loading represents about $35 \%$ of the entire weight of the catalyst layer (without the PTFE). This result is in line with previous studies [28-35]. 
ii) custom-made MEA with one plasma prepared electrode used either on the anode side or on the cathode side.

As with the commercial electrodes, the effect of the Nafion ${ }^{\circledR}$ loading added on the sputtered electrodes is investigated, in term of MEA performance. Four $5 \mathrm{~cm}^{2}$ GDLs are catalysed by plasma sputtering during 25 min (total Pt loading of $0.1 \mathrm{mg}_{\mathrm{Pt}} \mathrm{cm}^{-2}$ ) and covered by different quantities of Nafion ${ }^{\circledR}: 0,0.5,1$ and $2 \mathrm{mg} \mathrm{cm}^{-}$ 2. These electrodes are then hot pressed with a Nafion ${ }^{\circledR} 115$ membrane and a commercial electrode, previously covered by $2 \mathrm{mg} \mathrm{cm}^{-2}$ of Nafion ${ }^{\circledR}$. Figure 4 a displays the $\mathrm{E}(j)$ characteristics of these four MEAs where the plasma prepared electrodes are on the anode side. After completion of each FC test, the MEA is flipped to characterize the plasma prepared electrode for the oxygen reduction (i.e. on the cathode side). The FC results are displayed on Figure $4 b$.
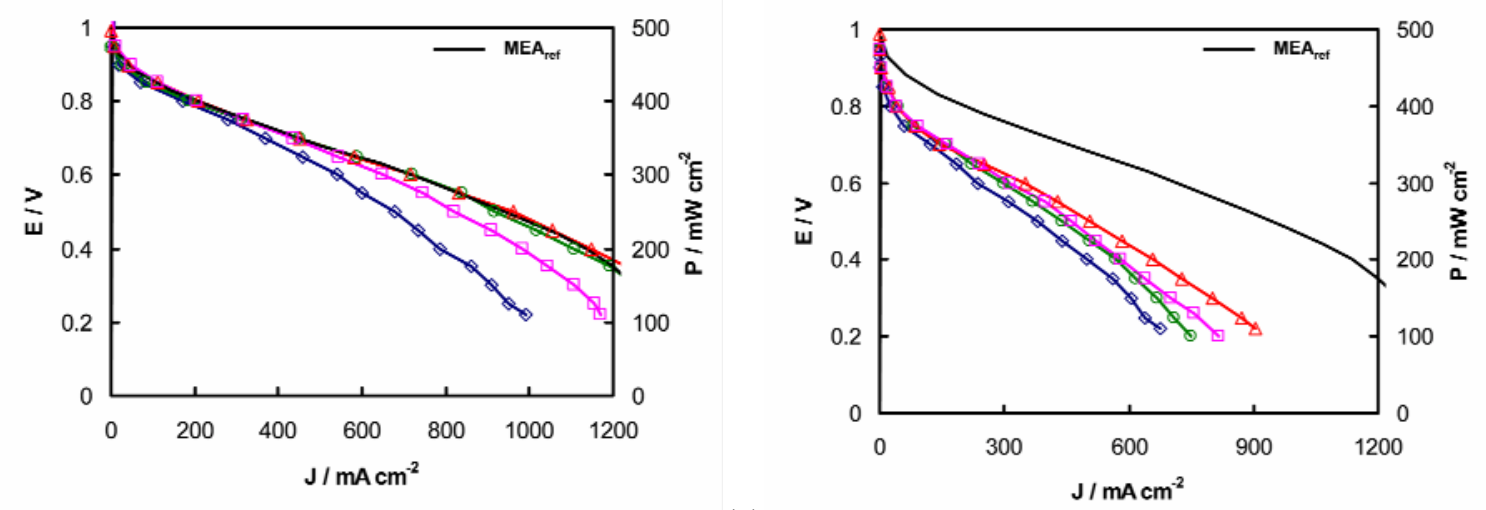

(a)

Figure 4. MEA performance obtained with four different Nafion ${ }^{\circledR}$ loadings on the plasma prepared electrode $\left(0.1 \mathrm{mg}_{\mathrm{Pt}} \mathrm{cm}^{-2}\right.$ of platinum) used on the anode side (a) and on the cathode side (b). The Nafion ${ }^{\circledR}$ loading applied on these electrodes is $(\bullet-) 0 \mathrm{mg}_{\mathrm{Pt}} \mathrm{cm}^{-2},(-) 0.5 \mathrm{mg}_{\mathrm{Pt}} \mathrm{cm}^{-2},(\triangle) 1 \mathrm{mg}_{\mathrm{Pt}} \mathrm{cm}^{-2}$ and $(\square) 2 \mathrm{mg}_{\mathrm{Pt}} \mathrm{cm}^{-2}$. Nafion ${ }^{\circledR} 115$ membrane and a commercial electrode covered by $2 \mathrm{mg} \mathrm{cm}^{-2}$ of Nafion ${ }^{\circledR}$ complete the four custom-made MEAs. The MEA $A_{\text {ref }}$ is composed of two reference electrodes with a Pt loading of $0.5 \mathrm{mg}_{\mathrm{Pt}} \mathrm{cm}^{-2}$ and a Nafion ${ }^{\circledR} 115$ membrane. Fuel cell operating conditions: $T_{\text {cell }}=80{ }^{\circ} \mathrm{C}, \mathrm{P}_{\mathrm{a}}=\mathrm{P}_{\mathrm{c}}=3$ bar, $\mathrm{D}_{\mathrm{a}} \sim \mathrm{D}_{\mathrm{c}} \sim 0.06$ L.min ${ }^{-1}$.

When Nafion ${ }^{\circledR}$ is not added to the anode catalyst layer, the resulting performance curve (diamond) is only slightly lower than that of the reference MEA. The two best performing anodes (circles and triangles) contain a loading of 0.5 and $1 \mathrm{mg} \mathrm{cm}^{-2}$, respectively and their performance equals that of the reference MEA. The $\mathrm{E}(j)$ curve drops for higher Nafion ${ }^{\circledR}$ loading : $2 \mathrm{mg} \mathrm{cm}^{-2}$ (squares). On Figure $4 \mathrm{~b}$, the reference MEA leads to much higher performance than all custom-made MEAs with a plasma prepared cathode, even with the optimum loading of Nafion ${ }^{\circledR}\left(1 \mathrm{mg} \mathrm{cm}^{-2}\right.$ - triangles).

For this type of electrode (prepared by plasma with a Pt 2 wt.\%/C catalyst ratio), the optimum Nafion ${ }^{\circledR}$ content represents about $20 \%$ of the overall $\mathrm{Pt} / \mathrm{C}$ weight. This is about half the optimum Nafion ${ }^{\circledR}$ content for the commercial electrode presented in the previous section and 2.5 times lower than the results reported by Sasikumar on electrodes prepared by ink-processes with a Pt loading of $0.1 \mathrm{mg}_{\mathrm{Pt}} \mathrm{cm}^{-2}$ [34]. This result is due to the location of the catalyst which is closer to the surface of the electrolyte in our plasma prepared 
electrode than in the electrodes prepared by ink-processes. Indeed, the morphology of the sputtered catalyst layer affects three mechanisms during the fuel cell operation. Firstly, as the Nafion ${ }^{\circledR}$ is spread on the surface of the GDL where most of the platinum is located, the Nafion ${ }^{\circledR}$ does not need to penetrate the GDL to create the three-phase interfaces. Secondly, if too much Nafion ${ }^{\circledR}$ is added, it will start blocking the pores deeper within the GDL and away from the catalyst layer. Thirdly, the Nafion ${ }^{\circledR}$ from the membrane is able to make sufficient contact with the catalyst, especially with the hot bonding, so that a higher level of performance is maintained at low Pt loading. However, a large amount of Nafion ${ }^{\circledR}$ may penetrate further than $2 \mu \mathrm{m}$ into the GDL where no platinum catalyst has been deposited by plasma sputtering. The technique used to deposit the Nafion ${ }^{\circledR}$ polymer may not be the most appropriate technique for coating the plasma catalysed GDL.

\subsection{Effect of the Pt loading in the plasma prepared anodes}

Two anodes with two Pt loadings $\left(0.005\right.$ and $\left.0.1 \mathrm{mg}_{\mathrm{Pt}} \mathrm{cm}^{-2}\right)$ are prepared under the same plasma conditions except for the deposition time ( 1 and 20 min, respectively). Each anode is hot pressed with a commercial cathode against a Nafion ${ }^{\circledR} 115$ membrane and with an optimized Nafion ${ }^{\circledR}$ loading of $1 \mathrm{mg} \mathrm{cm}^{-2}$. Figure 5 shows the polarization curves of these two custom-made MEAs at three different backpressures $\left(\mathrm{P}_{\mathrm{a}}=\mathrm{P}_{c}\right): 3$ bar (Figure 5a), 2 bar (Figure 5b) and 1 bar (Figure 5c). These curves (triangles and squares) are compared to those obtained with the reference MEA (solid line). The decrease of Pt loading (up to $0.01 \mathrm{mg}_{\mathrm{Pt}} \mathrm{cm}^{-2}$ ) by using plasma sputtering (squares and triangles) on the anode side does not affect the cell voltage for a current density lower than $500 \mathrm{~mA} \mathrm{~cm}^{-2}$ at 3 bar $\left(<200 \mathrm{~mA} \mathrm{~cm}^{-2}\right.$ at 2 bar and $<100 \mathrm{~mA} \mathrm{~cm}^{-2}$ at 1 bar). However, a decrease in the cell voltage at medium and high current density is observed for the two custom-made MEAs. This drop in performance is more important at low backpressure (Figure 5c) and for the Pt loading of 0.005 $\mathrm{mg}_{\mathrm{Pt}} \mathrm{cm}^{-2}$ (triangles) than for $0.1 \mathrm{mg}_{\mathrm{Pt}} \mathrm{cm}^{-2}$ (squares). This degradation at medium and high current density is due to the increase of the cell resistance with the decrease of the backpressure and the decrease of the $\mathrm{Pt}$ active site density. This effect has been illustrated previously in the literature [40]. This increase may be related to the decrease of the reactant concentration near the catalyst (decrease of the effective porosity of the catalytic layer by the flooding of the electrode and decrease of the reactant pressure). In a plasma prepared anode, all the platinum is located at the membrane-electrode interface which renders the membrane-electrode interface hydrophilic. Thus, the thin catalyst layer prepared by plasma is much more affected by the water coming from the cathode than a hydrophobic commercial anode where the platinum is dispersed over a large volume. This is especially problematic at high current densities where water should be properly removed from the electrode catalyst layer. This flooding effect is enhanced at low backpressure because the pressure drop between the inlet and the outlet of the cell is decreased.

In summary, the Pt loading can be decreased down to $0.005 \mathrm{mg}_{\mathrm{Pt}} \mathrm{cm}^{-2}$ using plasma sputtering, without decreasing the FC performance at low current and high pressure $(\mathrm{P}=3 \mathrm{bar})$. In this case, the efficiency of the anode catalyst reaches $85 \mathrm{~kW} \mathrm{~g} \mathrm{gt}_{\mathrm{Pt}}{ }^{-1}$ which is 100 times higher than that for the commercial anode. But, the performance is more sensitive to the Pt loading when the backpressure decreases, especially at high current density. 


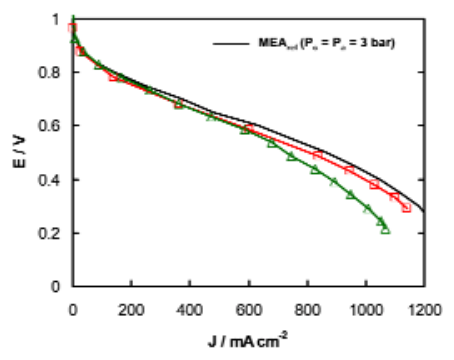

(a)

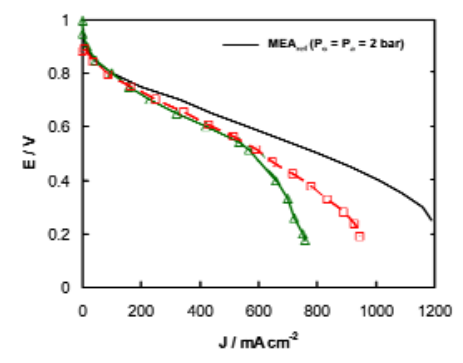

(b)

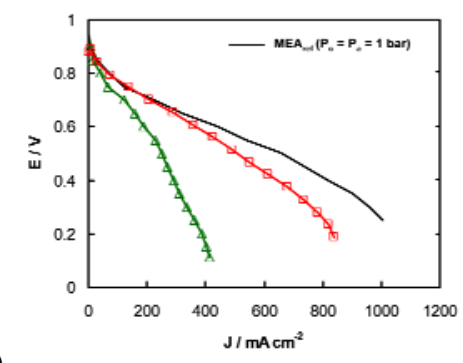

Figure 5. MEA performance versus Pt loadings in the anode prepared by plasma sputtering for different backpressures. Anode Pt loading: $(\triangle) 0.005 \mathrm{mg}_{\mathrm{Pt}} \mathrm{cm}^{-2},(\square) 0.1 \mathrm{mg}_{\mathrm{Pt}} \mathrm{cm}^{-2}$. Backpressure Pa and Pc: (a) 3 bar, (b) 2 bar and (c) 1 bar. MEA ${ }_{\text {ref }}$ is composed of two reference electrodes with a Pt loading of $0.5 \mathrm{mg}_{\mathrm{Pt}} \mathrm{cm}^{-}$ ${ }^{2}$ and a Nafion ${ }^{\circledR} 115$ membrane. Fuel cell operating conditions: $T_{\text {cell }}=80{ }^{\circ} \mathrm{C}, \mathrm{D}_{\mathrm{a}} \sim \mathrm{D}_{\mathrm{c}} \sim 0.06 \mathrm{~L} \cdot \mathrm{min}^{-1}$.

\subsection{Effect of the Pt loading in the plasma prepared cathodes}

Five different Pt loadings $\left(0.005,0.01,0.02,0.04\right.$ and $\left.0.1 \mathrm{mg}_{\mathrm{Pt}} \mathrm{cm}^{-2}\right)$ are deposited on the GDL by plasma sputtering for tests at the cathode. Each cathode is covered by a Nafion loading of $1 \mathrm{mg} \mathrm{cm}^{-2}$ and hot pressed with a commercial anode on Nafion ${ }^{\circledR} 115$ membrane. The $\mathrm{E}(j)$ cell voltage versus current density curves of the five custom-made is measured and compared to that of reference MEA in Figure 6.

Firstly, the sputtered cathodes lead to a lower electrical performance than that of the reference MEA in terms of achieved current densities at a given cell voltage. Secondly, the cell voltage strongly increases at low current density with cathode Pt loading increasing from 0.005 (triangles) to $0.1 \mathrm{mg}_{\mathrm{Pt}} \mathrm{cm}^{-2}$ (squares), which was not seen for the plasma prepared anode (Figure 5). Consequently, the increase of the Pt loading by plasma sputtering has a more important role on the activity of the oxygen reduction than on the hydrogen oxidation.

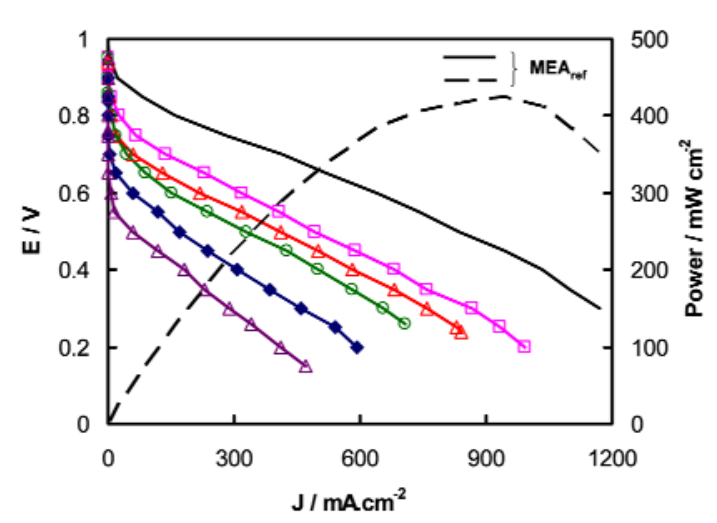

Figure 6. Polarization curves for the reference MEA (-) and five custom-made MEAs composed of a plasma prepared cathode with five different Pt loadings: $(-) 0.005 \mathrm{mg}_{\mathrm{Pt}} \mathrm{cm}^{-2},(-) 0.01 \mathrm{mg}_{\mathrm{Pt}} \mathrm{cm}^{-2},(-) 0.02 \mathrm{mg}_{\mathrm{Pt}}$ $\mathrm{cm}^{-2},(\triangle) 0.04 \mathrm{mg}_{\mathrm{Pt}} \mathrm{cm}^{-2}$ and $(\square) 0.1 \mathrm{mg}_{\mathrm{Pt}} \mathrm{cm}^{-2}$. (-). A commercial anode and a Nafion ${ }^{\circledR} 115$ membrane complete the custom-made MEAs. The anode and cathode Nafion ${ }^{\circledR}$ loading are 2 and $1 \mathrm{mg}_{\mathrm{Pt}} \mathrm{cm}^{-2}$, respectively. $\mathrm{MEA}_{\mathrm{ref}}$ is composed of two reference electrodes with a Pt loading of $0.5 \mathrm{mg}_{\mathrm{Pt}} \mathrm{cm}^{-2}$ and a Nafion ${ }^{\circledR} 115$ membrane. Fuel cell operating conditions: $T_{\text {cell }}=80{ }^{\circ} \mathrm{C}, \mathrm{P}_{\mathrm{a}}=\mathrm{P}_{\mathrm{c}}=3$ bar, $\mathrm{D}_{\mathrm{a}} \sim \mathrm{D}_{\mathrm{c}} \sim 0.06 \mathrm{~L}^{\mathrm{min}}{ }^{-1}$. 
Table 1 gives the values of $\mathrm{E}_{0}, \mathrm{~b}, \mathrm{R}_{\text {cell }}$ and $j_{0}$ drawn from Figure 6 . The increase of the fuel cell performance when increasing the sputtered Pt loading is related to the increase of the oxygen kinetics (increase of the Tafel slope from 0.04 to $0.07 \mathrm{~V} \mathrm{decade}^{-1}$ and of $j_{0}$ by more than three orders of magnitude with the increase of the cathodic Pt loading from 5 to $100 \mu \mathrm{g}_{\mathrm{Pt}_{\mathrm{t}}} \mathrm{cm}^{-2}$ ). In addition, the overall resistance of the system decreases when increasing the Pt loading (from 0.7 to $0.45 \Omega \mathrm{cm}^{2}$ ), with a more pronounced effect in the high current density region. This increase of the cell resistance can likely be related to the decrease of the density of platinum active sites in this thin catalyst layer when the cathodic Pt loading decreases.

Table 1. Electrode kinetic parameters for oxygen reduction drawn from $E(j)$ curves of Figure 6.

\begin{tabular}{cccccc}
\hline $\begin{array}{c}\text { Cathode Pt } \\
\text { loading } \\
\left(\mathrm{mg}_{\mathrm{Pt}} \mathrm{cm}^{-2}\right)\end{array}$ & $\begin{array}{c}\mathrm{E}_{\mathrm{r}} \\
(\mathrm{V})\end{array}$ & $\begin{array}{c}\mathrm{j}_{0} \\
\left(\mathrm{x} 10^{9} \mathrm{~A} \mathrm{~cm}^{-2}\right)\end{array}$ & $\begin{array}{c}\mathrm{b} \\
(\mathrm{V} \mathrm{decade})\end{array}$ & $\begin{array}{c}\mathrm{E}_{0} \\
(\mathrm{~V})\end{array}$ & $\begin{array}{c}\mathrm{R}_{\text {cell }} \\
\left(\Omega \mathrm{cm}^{2}\right)\end{array}$ \\
\hline 0.005 & 0.76 & 0.02 & 40 & 0.49 & 0.70 \\
0.01 & 0.84 & 0.7 & 50 & 0.57 & 0.64 \\
0.02 & 0.89 & 2 & 54 & 0.62 & 0.48 \\
0.04 & 0.92 & 3 & 58 & 0.66 & 0.46 \\
0.1 & 0.95 & 10 & 60 & 0.70 & 0.45 \\
\hline
\end{tabular}

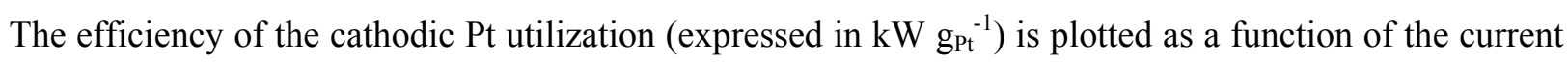
density in Figure 7. The maximum specific power density reaches $0.85 \mathrm{~W} \mathrm{~g}_{\mathrm{Pt}}{ }^{-1}$ for a commercial cathode (dashed line) and $22.5 \mathrm{~W} \mathrm{~g} \mathrm{gt}_{\mathrm{Pt}}{ }^{-1}$ for the plasma prepared cathode (triangles) with $0.005 \mathrm{mg}_{\mathrm{Pt}} \mathrm{cm}^{-2}$ of platinum, which reveals Pt utilization 26.4 times higher in this ultra low Pt loaded cathode than that in the commercial cathode. However, the Pt utilization efficiency in the sputtered electrodes drastically decreases as the Pt loading increases. The lowest efficiency of $2.7 \mathrm{~kW} \mathrm{~g}_{\mathrm{Pt}}{ }^{-1}$ obtained with $0.1 \mathrm{mg}_{\mathrm{Pt}} \mathrm{cm}^{-2}$ (squares) is still 3 times higher than that in the commercial electrode (the maximum power density is 1.5 times lower, whereas the catalytic load is 5 times lower). These Pt utilization efficiencies are consistent with the results obtained by Gruber et al [41], especially for a Pt loading lower than $0.05 \mathrm{mg}_{\mathrm{Pt}} \mathrm{cm}^{-2}$. For a Pt loading superior to $0.05 \mathrm{mg}_{\mathrm{Pt}}$ $\mathrm{cm}^{-2}$, they report a lower efficiency than that reported here. This difference may be explained by the FC operating conditions: room temperature and ambient pressure in Ref [42] (here $80^{\circ} \mathrm{C}$ and 3 bar testing conditions). In addition, the plasma sputtering conditions (deposition system geometry, plasma antenna, argon pressure, RF power) are very different and this may contribute to the performance improvement of our electrodes via variations in the flux and the energy of the species ( $\mathrm{Pt}$ and Ar atoms, ions and electrons) impinging onto the GDL during the deposition process. However, the difference in performance between their reference MEA and their custom-made MEA is very low $\left(12 \%\right.$ with a Pt loading of $0.08 \mathrm{mg}_{\mathrm{Pt}} \mathrm{cm}^{-2} \mathrm{Pt}$ sputtered on the ETEK GDL). Here, the difference is found to be $36 \%$ for a Pt loading of $0.1 \mathrm{mg}_{\mathrm{Pt}} \mathrm{cm}^{-2}$. 


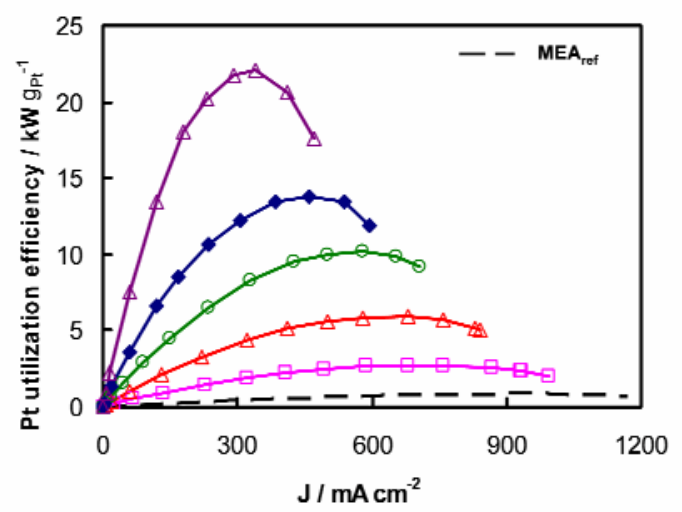

Figure 7. Platinum utilization efficiency $\left(\mathrm{kW} \mathrm{g}_{\mathrm{Pt}}{ }^{-1}\right)$ versus current density drawn from $E(j)$ curves of Figure 6. The Pt loading of the five plasma-prepared cathodes is $(\triangle) 0.005 \mathrm{mg}_{\mathrm{Pt}} \mathrm{cm}^{-2},(\neg-) 0.01 \mathrm{mg}_{\mathrm{Pt}} \mathrm{cm}^{-2},(-)$ $0.02 \mathrm{mg}_{\mathrm{Pt}} \mathrm{cm}^{-2},(-) 0.04 \mathrm{mg}_{\mathrm{Pt}} \mathrm{cm}^{-2}$ and $(\square) 0.1 \mathrm{mg}_{\mathrm{Pt}} \mathrm{cm}^{-2}$. (-). A commercial anode and a Nafion ${ }^{\circledR} 115$ membrane complete the custom-made MEAs. The anode and cathode Nafion ${ }^{\circledR}$ loading are 2 and $1 \mathrm{mg}_{\mathrm{Pt}} \mathrm{cm}^{-2}$, respectively. $\mathrm{MEA}_{\text {ref }}$ is composed of two reference electrodes with a Pt loading of $0.5 \mathrm{mg}_{\mathrm{Pt}} \mathrm{cm}^{-2}$ and a Nafion ${ }^{\circledR} 115$ membrane. Fuel cell operating conditions: $T_{\text {cell }}=80 \circ \mathrm{C}, \mathrm{P}_{\mathrm{a}}=\mathrm{P}_{\mathrm{c}}=3$ bar, $\mathrm{D}_{\mathrm{a}} \sim \mathrm{D}_{\mathrm{c}} \sim 0.06 \mathrm{~L} \cdot \mathrm{min}^{-1}$.

The Pt cost can be further reduced by the replacement of the Nafion ${ }^{\circledR} 115$ by a Nafion ${ }^{\circledR} 112$ membrane. In this case, the $0.1 \mathrm{mg}_{\mathrm{Pt}} \mathrm{cm}^{-2}$ loaded cathode prepared for the same plasma conditions leads to a $\mathrm{Pt}$ efficiency of $4 \mathrm{~kW} \mathrm{~g} \mathrm{gt}_{\mathrm{Pt}}^{-1}$ (i.e. $0.25 \mathrm{~g}_{\mathrm{Pt}} \mathrm{kW}^{-1}$ ) compared to $1.8 \mathrm{~kW} \mathrm{~g}_{\mathrm{Pt}}^{-1}$ with a commercial cathode.

\subsection{Plasma sputtering deposition of high Pt loading.}

Figure 8 displays the maximum power densities $\mathrm{P}_{\max }$ (filled diamonds) and the power densities at $300 \mathrm{~mA}$ $\mathrm{cm}^{-2} \mathrm{P}_{j=300}$ (open diamonds) achieved by seven custom-made MEAs fitted with one plasma prepared cathode and the the reference MEA as a function of the cathodic Pt loading. The power densities for loadings below $0.1 \mathrm{mg}_{\mathrm{Pt}} \mathrm{cm}^{-2}$ are drawn from the $\mathrm{E}(j)$ curves of Figure 6 and the power densities at 0.26 and $0.44 \mathrm{mg}_{\mathrm{Pt}} \mathrm{cm}^{-2}$ correspond to two additional custom-made MEAs prepared under similar conditions as the five previous ones (commercial anode and Nafion ${ }^{\circledR} 115$ membrane).

For low Pt loading $\left(<100 \mu \mathrm{g}_{\mathrm{Pt}} \mathrm{cm}^{-2}\right)$, both power densities $\left(\mathrm{P}_{\max }\right.$ and $\left.\mathrm{P}_{j=300}\right)$ obtained with the custommade MEAs increase with increasing Pt loading and are well fitted by two logarithmic curves (dashed lines) which asymptotically reach the values of the reference MEA with $500 \mu \mathrm{g}_{\mathrm{Pt}} \mathrm{cm}^{-2}$. For high Pt loading $(\geq 100$ $\mu \mathrm{g}_{\mathrm{Pt}} \mathrm{cm}^{-2}$ ), the power densities of the custom-made MEAs show values lower than the respective logarithmic fitting curve. The deviation between the experimental data and the logarithmic curves increases in amplitude with increasing Pt loading. It has been previously shown that about $75 \%$ of the platinum atoms supported on the Vulcan particles are spread over a GDL depth of $200 \mathrm{~nm}$ [38]. The available surface of carbon is about $30 \mathrm{~cm}^{2}$ in this thin layer for a $1 \mathrm{~cm}^{2}$ geometric area, by assuming a $30 \mathrm{~nm}$ in diameter sphere packing arrangement with the optimum carbon density of about $74 \%$ (which corresponds to the cubic or the hexagonal close packing - Keppler conjecture). Therefore, the decrease of the power density (and the deviation from the logarithmic curve) occurs when $910^{15} \mathrm{Pt}$ atoms are deposited on a Vulcan specific area of 
$1 \mathrm{~cm}^{2}$. For such a surface density, the Pt nano-clusters increase in size by branching with other nano-cluster until the formation of a percolation network on the entire substrate area (Pt catalytic film) according to a previous study on the deposition of Pt atoms by plasma sputtering [43]. Consequently, the decrease of the power density and the deviation from the logarithmic curves are likely be related to the transition from separated nano-clusters to a Pt percolated layer. This is confirmed by the SEM observations of Figure $2 \mathrm{~b}$ and by previous studies [38]. This transformation leads to a decrease of the electrochemically active surface area at the membrane-electrode interface. In addition, the Pt thin film layer at the electrode-membrane interface becomes denser with the increasing Pt loading and resulting in some blocking of the fuel and water transport. This results in a higher resistance and in a lower electrochemically active surface area of the sputtered catalyst.

These results demonstrate that an optimization of the plasma parameters (argon pressure, target bias, RF power, GDL bias) is required to increase the platinum penetration into the GDL to avoid the formation of the catalytic film. The deposition of a catalyst supporting sublayer to improve the catalyst accessibility to the gas and its morphology in replacement or in complement of the Vulcan based GDL is another solution. Sublayers based on rod-shaped carbon nanostructures (with a high open porosity) or based on metal and polymer materials are currently envisaged [35, 43].

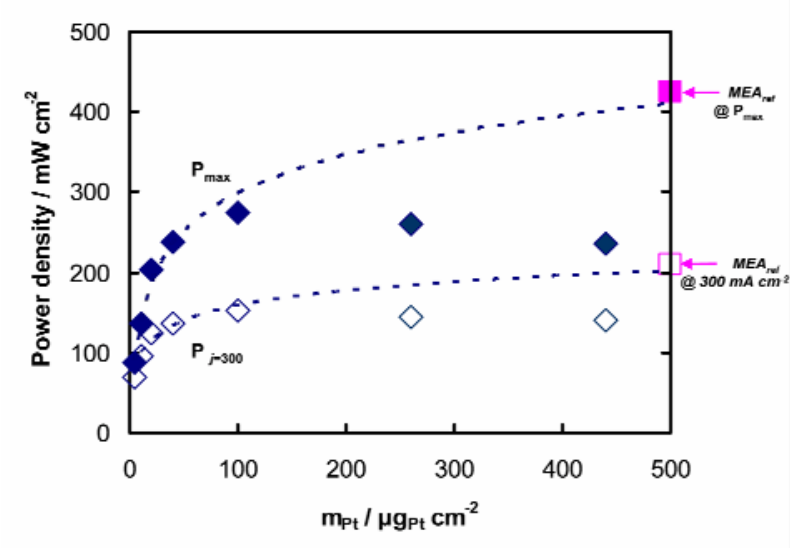

Figure 8. Maximum power density $\mathrm{P}_{\max }(\diamond)$ and power density at $300 \mathrm{~mA} \mathrm{~cm}{ }^{-2} \mathrm{P}_{j=300}(\diamond)$ achieved by seven custom-made MEAs as a function of the cathode Pt loading $\left(\mathrm{m}_{\mathrm{Pt}}\right)$. Both power densities are fitted with a logarithmic curve (- - ). $\mathrm{P}_{\max }(\square)$ and $\mathrm{P}_{j=300}(\square)$ obtained with the reference MEA are reported on the graph for $\mathrm{m}_{\mathrm{Pt}}=500 \mu \mathrm{g}_{\mathrm{Pt}} \mathrm{cm}^{-2}$. Fuel cell operating conditions: $T_{\text {cell }}=80{ }^{\circ} \mathrm{C}, \mathrm{P}_{\mathrm{a}}=\mathrm{P}_{\mathrm{c}}=3$ bar, $\mathrm{D}_{\mathrm{a}} \sim \mathrm{D}_{\mathrm{c}} \sim 0.06 \mathrm{~L} \cdot \mathrm{min}^{-1}$.

Figure 9 displays the cathodic Pt utilization of these eight MEAs calculated at $\mathrm{P}_{\max }$ (filled symbols) and $\mathrm{P}_{\mathrm{j}=300}$ (open symbols) as a function of the cathodic Pt loading. The two logarithmic fits of Figure 8 are added on Figure 9. The Pt utilization taken at $P_{\max }$ or at $j=300 \mathrm{~mA} \mathrm{~cm}{ }^{-2}$ is higher in the plasma prepared cathode than in the commercial cathode for a sputtered Pt loading lower than $0.26 \mathrm{mg} \mathrm{cm}^{-2}$ (and inversely for a Pt loading higher than $0.26 \mathrm{mg} \mathrm{cm}^{-2}$ ). 


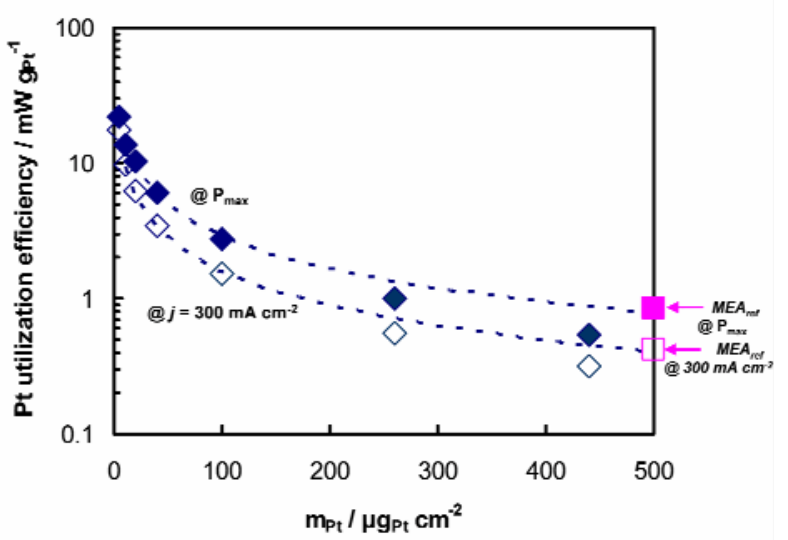

Figure 9. Platinum utilization efficiency obtained for the maximum power density $P_{\max }(\bullet)$ and for the power density at $300 \mathrm{~mA} \mathrm{~cm}^{-2}(\diamond)$ and achieved by seven custom-made MEAs as a function of the cathode Pt loading $\left(\mathrm{m}_{\mathrm{Pt}}\right)$. The Pt utilization efficiency obtained with the reference MEA for $\mathrm{P}_{\max }(\square)$ and for $\mathrm{P}_{j=300}(\square)$ are reported on the graph. Fuel cell operating conditions: $T_{\text {cell }}=80 \circ \mathrm{C}, \mathrm{P}_{\mathrm{a}}=\mathrm{P}_{\mathrm{c}}=3$ bar, $\mathrm{D}_{\mathrm{a}} \sim \mathrm{D}_{\mathrm{c}} \sim 0.06 \mathrm{~L} \cdot \mathrm{min}^{-1}$.

\section{Conclusion}

A plasma sputtering process has been used to deposit platinum on GDL and to decrease the catalyst loading in the anode and the cathode. The optimum Nafion ${ }^{\circledR}$ loading for an electrode covered by $0.1 \mathrm{mg}_{\mathrm{Pt}} \mathrm{cm}^{-2}$ of platinum is $1 \mathrm{mg} \mathrm{cm}^{-2}$, which is half the optimized Nafion ${ }^{\circledR}$ in a commercial electrode. At high operating pressure, an anode prepared with a sputtered Pt loading of $0.005 \mathrm{mg}_{\mathrm{Pt}} \mathrm{cm}^{-2}$ leads to the same electrical performance than that of a reference MEA (purchased at Electrochem. Inc., Nafion ${ }^{\circledR} 115$ membrane and two electrodes with $0.5 \mathrm{mg}_{\mathrm{Pt}} \mathrm{cm}^{-2}$ of platinum), although the platinum amount is 100 times lower. The activity of the sputtered catalyst in a cathode is lower than that obtained with a commercial cathode of Pt loading 0.5 $\mathrm{mg}_{\mathrm{Pt}} \mathrm{cm}^{-2}$. Yet, the specific activity is much higher, indicating that the efficiency of use of the sputtered $\mathrm{Pt}$ catalyst is higher than that in a commercial cathode. The platinum specific activity decreases when the catalyst loading is increased on the GDL. The cathodic Pt efficiency reaches $2.7 \mathrm{~kW} \mathrm{~g}_{\mathrm{Pt}}{ }^{-1}$ and $22.5 \mathrm{~kW} \mathrm{~g}_{\mathrm{Pt}}{ }^{-1}$ with a cathodic Pt loading of respectively $0.1 \mathrm{mg}_{\mathrm{Pt}} \mathrm{cm}^{-2}$ and $0.005 \mathrm{mg}_{\mathrm{Pt}} \mathrm{cm}^{-2}$ deposited by plasma sputtering and $0.85 \mathrm{~kW} \mathrm{~g} \mathrm{gt}_{\mathrm{P}}{ }^{-1}$ with a commercial cathode. Future durability experiments will need to be carried out to establish the long time stability of these catalysts. The utilization efficiency of the deposited platinum can still be improved by the optimization of the sputtering parameters and/or the growth of a catalyst supporting sublayer.

\section{Acknowledgements}

We would like to thank P. Alexander (ANU) for precious technical help on Southern Cross and on the Fuel cell Station, C.Coutanceau (Laboratoire de Catalyse en Chimie Organique, France) for precious discussion on fuel cell tests and S. Stowe (Electron Microscopy Unit, ANU) for assistance with the SEM analysis.

\section{References}


[1] U.S. Department of Energy (Hydrogen, Fuel cells \& Infrastructure Technologies Program), "Multi-Year Research, Development and Demonstration Plan: Planned Program Activities for 2005-2015" http://www1.eere.energy.gov/hydrogenandfuelcells/mypp/

[2] C.H. Hsu, C.C. Wan, J. Power Sources 115 (2003) 268.

[3] G. Sasikumar, M. Raja, S. Parthasarathy, Electrochem. Acta 40 (1995) 285.

[4] G. Sasikumar, J. W. Ihm, H. Ryu, J. Power sources 132 (2004) 11

[5] C.S. Kim, Y.G. Chun, D.H. Peck, D.R. Shin, Int. J. Hydrogen Energy 23 (1998) 1045.

[6] E.A. Ticianelli, J.G. Beery, S. Srinivasan, J. Appl. Electrochem. 21 (1991) 597.

[7] M. W. Verbrugge, J. Electrochem. Soc. 141 (1994) 46.

[8] K.H. Choi, H.S. Kim, T.H. Lee, J. Power Sources 75 (1998) 230.

[9] S. Mukerjee, S. Srinivasan, A.J. Appleby, Electrochem. Acta 38 (1993) 1661.

[10] S. Hirano, J. Kim, S. Srinivasan, Electrochim. Acta, 42 (1997) 1587.

[11] P. Brault, A. Caillard, A.-L. Thomann, J. Mathias, C. Charles, R.W. Boswell, S. Escribano, J. Durand,T. Sauvage, J. Phys. D: Appl. Phys. 37 (2004) 3419.

[12] A. Caillard, P. Brault, J. Mathias, C. Charles, B.W. Boswell, T. Sauvage, Surf. Coat. Technol. 200 (2005) 391.

[13] A. Caillard, C. Coutanceau, P. Brault, J. Mathias, J.-M. Léger, J. Power Sources, 162 (2006) 66.

[14] P. Brault, S. Roualdès, A. Caillard, A.L. Thomann, J. Mathias, J. Durand, C. Coutanceau, J.M. Leger, C. Charles and R.W. Boswell, Eur. Phys. J. Appl. Phys. 34 (2006) 151.

[15] L. Mex, N. Ponath, J. Müller, Fuel cell Bulletin, 39.

[16] K.L. Huang, Y.C. Lai, C.H. Tsai, J. Power Sources, 156 (2006) 224.

[17] M. Alvisi, G. Galtieri, L. Giorgi, R. Giorgi, E. Serra, M.A. Signore, Surf. Coat. Technol. 200 (2005) 1325.

[18] C.H. Wan, M.T. Lin, Q.H. Zhuang, C.H. Lin, Surf. Coat. Technol. 201 (2006) 214.

[19] K. Makino, K. Furukawa, K. Okajima, M. Sudoh, Electrochim. Acta, 51 (2005) 961.

[20] C. K. Witham, W. Chun, T. I. Valdez, S. R.Narayama, Electrochem. Solid-State Lett. 3 (2000) 497.

[21] A.T. Haug, R.E. White J. W. Weidner, W. Huang, S. Shi, T. Stoner, N. Rana, J. Electrochem. Soc. 149 (2002) A280.

[22] A.T. Haug, R.E. White J. W. Weidner, W. Huang, J. Electrochem. Soc. 149 (2002) A862.

[23] A.T. Haug, R.E. White J. W. Weidner, W. Huang, S. Shi, N. Rana, S. Grunow, T. Stoner, , J. Electrochem. Soc. 149 (2002) A868.

[24] C.L. Chang, T.C. Chang, W.Y. Ho, J.J. Hwang, D.Y. Wang, Surf. Coat. Technol. 210 (2006 4442.

[25] S. Y. Cha, W. M. Lee, J. Electrochem. Soc. 146 (1999) 4055.

[26] R. O’Hayre, S.J. Lee, S.W. Cha, F.B. Prinz, J. Power Sources, 109 (2002) 483.

[27] J.-H. Wee, K.-Y. Lee, S.H. Kim, J.Power Sources 165 (2007) 667

[28] V. A. Paganin, E. A. Ticianelli and E. R. Ganzalez,. Journal of Applied Electrochemistry, 26 (1996) 297. 
[29] E. A. Ticianelli, C. R. Derouin, A. Redondo and S. Srinivasan, Journal of The Electrochemical Society, 135 (1988) 2209.

[30] S. Gamburzev and A. J. Appleby, Journal of Power Sources, 107 (2002) 5.

[31] E. Passalacqua, F. Lufrano, G. Squadrito, A. Patti and L. Giorgi, Electrochimica Acta, 46 (2001) 799.

[32] E. Antolini, L. Giorgi, A. Pozio, E. Passalacqua, J. Power Sources 77 (1999) 136.

[33] J. M. Song, S. Y. Cha and W. M. Lee, Journal of Power Sources, 94 (2001) 78.

[34] G.Sasikumar, J.W. Ihm, H. Rhyu, Electrochemica Acta, 50 (2004) 601.

[35] S. J. Lee, S. Mukerjee, J. McBreen, Y. W. Rho, Y. T. Kho and T. H. Lee, Electrochimica Acta, 43 (1998) 3693.

[36] A. Caillard, C. Charles, R. Boswell, P. Brault, nanotechnology 18 (2007) 305603.

[37] A. Caillard, C. Charles, R. Boswell, P. Brault, C. Coutanceau, Appl. Phys. Lett. 90 (2007) 223119.

[38] A. Caillard, PhD thesis, The Australian National University and l'université d'Orléans, Australia and France (2006).

[39] D. Ramdutt, $\mathrm{PhD}$ thesis, The Australian National University, Australia (2007).

[40] A.J.-J. Kadjo, P. Brault, A. Caillard, C. Coutanceau, J.-P. Garnier, S. Martemianov, Journal of Power Sources 172 (2007) 613

[41] D. Gruber, N. Ponath, J.Müller, F. Lindstaedt, J. Power Sources 150 (2005) 67

[42] D. Gruber, J. Müller, J. Power Sources 171 (2007) 294

[43] P. Andreazza, C. Andreazza-Vignolle, J.P. Rozenbaum, A.-L. Thomann, P. Brault, Surf. Coat. Technol. 151 (2002) 122 